\title{
Compulsive Buying Behavior and Its Impact on Borrowing Habit
}

\author{
SUPRAMONO \\ Satya Wacana Christian University, Indonesia \\ supramono@staff.uksw.edu \\ IWI RAMBU KARERI \\ Satya Wacana Christian University, Indonesia \\ iwi_yaboe@yahoo.co.id
}

The aim of this study is to analyze the effect of pocket money, peer acceptance, and money retention on Compulsive Buying Behavior (свв) and borrowing habit, as well as the effect of свв on borrowing habit and the mediating effect of свв. The samples of this study were the undergraduate students. A total of two hundred questionnaires were obtained and analyzed by using Structural Equation Modelling (SEM). The result of this study showed that peer acceptance and money retention had an impact in determining the level of свв. Meanwhile, pocket money and peer acceptance did not affect borrowing habit. On the other hand, only money retention that had the direct effect on borrowing habit. Moreover, this study also found that свв mediated the effect of money retention on borrowing habit.

Key words: compulsive buying behavior, borrowing habit, pocket money, peer acceptance, money retention

https://doi.org/10.26493/1854-4231.13.3-17

\section{Introduction}

Economic theories claim that purchases are made to obtain utility. In fact, there are many people making purchases to get satisfaction from the purchasing process instead of achieving utility. Dittmar (2005) argued that this kind of people purchase in order to improve their mood as well as to increase their confidence. Besides, DeSarbo and Edwards (1996) stated that these people make purchases to escape from stress and anxiety. This kind of people is called compulsive buyers (O'Guinn and Faber 1989). The behavior shown by compulsive buyers in the study of consumer behavior is called compulsive buying behavior (свв). The process of buying is considered as a pleasurable activity to compulsive buyers so that they are often labeled as the hedonists.

свв can lead to addictive shopping. Some studies found that a high tendency of свв is found in some countries like India (Jalees 2007), 
Thailand and China (Guo and Cai 2011). This behavior is often classified as a behavioral disorder that needs to be prevented or removed from those who are now suffering from свв. Many people have perceived this negative behavior as a common behavior in the world's materialistic culture. This action can be as difficult to stop as any other compulsions or addictions.

Previous studies, however, have investigated the relationship between many variables and свв. Guo and Cai (2011) found that pocket money is a common factor that predicts свв. Another determinant of свв is the influence of peers (Moschis et al. 2013). In addition to both factors explained above, money retention is also proven influence свв. People who are not careful in using their money are more likely to do Свв (Li et al. 2009). However, most previous studies investigated свв within the scope of marketing. Four of them are the studies conducted by Vicdan and Sun (2008) that examined the relationship between свв and online sales promotion; and also the study that was carried out by Jalees (2007); Bindah and Othman (2012) and Khaniwale (2015) that explored the determinants of свв.

Furthermore, свв generates several problems for the compulsive buyers themselves, their families, friends, and their colleagues (Ergin 2010). Many compulsive buyers will have problems with their debts. In the case of having one or more credit cards, Wilczaki (2006) found that many compulsive buyers have been crippled by their debts. When compulsive buyers do not have a credit card, it is possible that they will borrow money from their parents and friends to buy some stuff. Therefore, borrowing money repeatedly will end up with a high borrowing habit that leads to other negative effects. Meanwhile borrowing habit itself can be affected by pocket money, peer acceptance, and money retention. People with higher pocket money may borrow money more often because they believe that they have the ability to pay back, and vice versa. In the term of peer acceptance, people who need to be accepted by their peers will have a greater possibility to borrow money from their peers. If it is linked to money retention, it is easy to imagine that people who use their money carefully will rarely borrow money because they are good at managing their money.

Previous studies simply analyzed the свв determinants without further analysis about its impacts. Therefore, this study will not only investigate the свв determinants, but also its effects on borrowing habit. Moreover, to examine свв from the financial point of view, this study would inspect the свв impacts on borrowing habit and would particularly investigate the direct and indirect effects of 
pocket money, peer acceptance, and money retention towards borrowing habit. Therefore formulated four research question are: (1) Do pocket money, peer acceptance, and money retention have a significant effect on свв? (2) Do pocket money, peer acceptance, and money retention has a direct effect on borrowing habit? (3) Does свв has a significant effect on borrowing habit? (4) Does свв mediate the effect of pocket money, peer acceptance, and money retention on borrowing habit? This study could be considered as one pioneering study that investigated borrowing habit, since there has not been found any previous studies that explored and examined borrowing habit

\section{Literature Review}

COMPULSIVE BUYING BEHAVIOR (CBB)

Свв is a buying behavior that is uncontrollable and significantly distressing, time-consuming, or resulting in social or financial difficulties (McElroy et al. 1994). The definition used in this study is adapted from Black (2007) who sees свв as excessive shopping cognitions that leads to distress or impairment. свв may be affected by students' pocket money. Furnham (1999) stated that pocket money is 'the money that has been given,' in his study, for young people. Pocket money, based on when it is earned, could be divided into two types: regular pocket money and irregular pocket money. If it is earned in every specific period of time, then it is called as a regular pocket money. However, if it is earned not in every specific period, then it is called as an irregular pocket money. The influence of pocket money on buying behavior has been investigated by Lin and Lin (2005). They found that when people have a large amount of pocket money, they tend to spend more.

The second factor that may affect свв is peer acceptance. Peer acceptance refers to the extent to which children are accepted or rejected by their peer group (Slaughter, Dennis, and Prichard 2002; Gifford-Smith and Brownell 2002). According to Bristol and Mangleburg (2005) peer acceptance about the extent to which peers exert influence on the attitudes, thoughts, and actions of an individual. Peer acceptance is best explained by the term utilitarian influence, in which an individual is willing to satisfy a certain group's expectation (Kelman 1961). People who have already been accepted by their peers don't do as much efforts to be welcomed as those who haven't. They also will buy something that their peers have already had to look the same with them. The study conducted by 
Guo and Cai (2011) proved that peers are one of свв determinants. Money retention is the last element proposed in this study as an aspect that influences свв. Taneja (2012) simplifies money attitude as the perception of money, and it is important because it plays a role as a money behavior determinant. One of the factors that influence consumer behavior is money attitude (Li et al. 2009). Yamauchi and Templer (1982) classified the money attitude in three domains: security, retention time, and power prestige. Besides having a significant effect on свв, Taneja (2012) also found money attitude as a factor that shapes people's money behavior. This study focuses specifically on one money attitude domain: money retention. In this research, money retention is simply defined as being careful in using money (Furnham 1984). People who are careful in using money will be able to restrain themselves for not wasting money to buy things they do not need. These are the people with high money retention.

\section{BORROWING HABIT}

When people borrow money more frequently, it becomes a borrowing habit. Since an explicit definition of borrowing habit cannot be found in the literature, this paper defines the borrowing habit as someone's tendency to borrow money from other people. People who have a small amount of money tend to be less confidence in borrowing money because they do not believe in their ability to pay back the loan. Callender and Jackson (2005) discovered that students from low-income family tend to debt-averse. Another similar finding stated that the low-income students are more likely to commit themselves to minimal borrowing (Linenmeier, Rosen, and Rouse 2006; De La Rosa and Luna 2012). The same logical thinking can be used to analyze how of the amount of pocket money influence someone's borrowing habit. The tendency of students with lower amount of pocket money to borrow money is less because they do not believe in their ability to pay the loan back.

Besides affecting свв, peer acceptance may also affect borrowing habit. A real example of that influence was found by Rindfleisch, Burroughs, and Denton (1997) who stated that peers could influence materialism. Moreover, Ponchio and Aranha (2008) detected that materialistic consumers are willing to carry heavier debt loads. If the credit card is seen as a person to whom people borrow money, then a number of money people borrow is too much when there is an overused credit. These findings suggest that it is possible that when peer acceptance is high, people tend to be more materialistic and to be materialistic increases their demand for money. 
Money retention may also have an effect on borrowing habit. People with high money retention are capable of managing their money. These people have the tendency to be careful financial planners (Wong 2010). Because of their capability of managing their money, these people also have a very low need or preference for loans (Bhardwaj and Bhattacharjee, 2010). People with high money retention, who are called as budget-minded individuals by Engelberg and Sjoberg (2006), are found to have less favorable attitudes towards borrowing money.

Edwards (1993) revealed that many cases of excessive borrowing result from compulsive spending. Workman and Paper (2010) called the people who love to borrow money because of their compulsive buying behavior as a compulsive debtor. Consumption is influenced by the amount of pocket money, salary, and some other sources of money given to someone (Bonke 2013) The effect of pocket money on impulsive buying behavior has been investigated by Lin and Lin (2005) and Guo and Cai (2011). The authors found that impulsive buying behavior tends to increase when there is an increase in the amount of pocket money. People with the large amount of money will not only become compulsive buyers, but also experience unmanageable debts because of their свв. In addition, the previous study held by Guo and Cai (2011) found that peers are one of the several determinants of свв. For purchasing things or goods are recorded as one of the key success factor to improve peers, many people are trapped in свв and debt problems. The indirect effect of money retention on borrowing habit is elaborated as follows. People who are careful in using money can restrain themselves for not wasting money to buy things they do not need. They prefer saving rather than spending, even when they have extra money. Hence, their buying behavior can be managed better, and they become more capable of controlling свв. Thus, they are able to control their debt and make minimal borrowing.

Based on the theoretical considerations, we propose the following hypotheses:

$\mathrm{H} 1 \mathrm{~A}$ Pocket money has a significant positive effect on свв.

н1в Peer acceptance has a significant positive effect on свв.

н1в Money has a significant positive effect on свв.

H2A Pocket money has a significant positive effect on borrowing habit.

н2в Peer acceptance has a significant positive effect on borrowing habit. 
н2с Money has a positive has a significant positive effect on borrowing habit.

н3 свв has a significant positive effect on borrowing habit.

н4А свв plays mediating role between pocket money and borrowing habit.

н4 $\mathrm{B}$ свв plays mediating role between peer acceptance and borrowing habit.

н4в свв plays mediating role between money retention and borrowing habit.

\section{Method}

QUESTIONNAIRE DESIGN AND MEASUREMENT

The survey questionnaire designed for this study was made up of two parts. Part A consists of questions requiring respondents to answer about their backgrounds, such as age, gender, origin, and some additional questions. Part B consists of questions related to borrowing habit, свв, and three other independent variables: peer acceptance, money retention, and pocket money. The process of questionnaire development involved pilot questionnaire tested on 17 students to check its clarity and some improvements were made based on the pre-test questionnaire.

The measurement of свв consists of four items adapted from a study by Valence, d'Astous, and Fortier (1988). The four items are having a strong urge and spontaneous desire to shop, having a difficulty to restrain the willingness to shop, purchasing unnecessary products, and considering shopping as a way to face the stress. The concept of peer acceptance was measured by using four items developed by Bearden, Netemeyer, and Teel (1989): using trendy products to get acceptance, using high-quality products to get acceptance, following friends to buy certain products, and using products that are favored by friends. Money retention measurement was based on the scale developed by Yamauchi and Templer (1982): not spending money easily, having the capability of managing money, saving money, and keeping track of the money. The pocket money was measured by the amount of money earned by students from their parents every month, and the amount was divided into five categories. Borrowing habit would be measured by four items: deciding to borrow money easily, considering borrowing as the easiest way to get money; not making much consideration before borrowing money, used to borrow money. Items were measured based on 5-point ratings of agreement ( 1 - strongly disagree, 5 - strongly agree). 
SAMPLE

The population of this study were all undergraduate students in the Faculty of Business and Economics, Satya Wacana Christian University, Indonesia. The total population was 1.095 students. This study was proposed to test the model by using SEM technique. Bentler and Chou (1987) suggested that in SEM the preferred ratio of sample size to a number of free parameters would be 10:1. Others also suggested a rule of thumb that ten subjects per item in scale development are prudent (Flynn and Pearcy 2001). In this study, the number of free parameters equals to 16 . Therefore, a sample size of 160 is required. However, Hair et al. (2010) recommended a sample size of 200 to test a model using SEM. It is a 'critical sample size' that can be used in any common estimation procedure for valid results. Thus, this study used the minimum sample size of 200.

\section{DATA COLLECTION}

Data collection was done by distributing questionnaires to certain classes, after getting the permission and having an appointment from the lecturer in charge. A total of 200 questionnaires were distributed to the target respondents, and they were given about twenty minutes to fill in the questionnaire. There were no incomplete questionnaires, so all of them were used in this study. The whole data was gathered within 3 weeks. The respondents' demographic profile showed that almost 64 percent of the respondents were female. Their ages ranged from 18 to 21 years, and most of them came from outside the area of the university. $76 \%$ of the students received less than Rp 950,000 per month as pocket money from their parents. Interestingly, $80 \%$ of the students admitted to set aside money for savings, and in case they experienced a lack of money, $60 \%$ of them choose to ask their parents for more money.

\section{Results}

The first step in data analysis was to check whether the result showed a goodness of fit model or not. There are three independent variables used in this study, and SEM analysis required them to be tested using Confirmatory Factor Analysis (CFA). The result of the CFA was reported in table 1, using eight goodness of fit indices, it could be concluded that all criteria were good as expected. Then, in the endogenous constructs, свв was considered as the intervening variable and borrowing habit as the dependent variable. The model evaluation reported that the model was good. 
TABLE 1 Exogenous and Endogenous Constructs Goodness of Fit Indices

\begin{tabular}{|c|c|c|c|c|c|}
\hline \multirow[t]{2}{*}{ Goodness of Fit Indices } & \multirow{2}{*}{$\begin{array}{l}\text { Cut-Off } \\
\text { Value }\end{array}$} & \multicolumn{2}{|c|}{ Exogenous const. } & \multicolumn{2}{|c|}{ Endogenous const. } \\
\hline & & (1) & (2) & $(1)$ & $(2)$ \\
\hline Chi-Square & * & 29.10 & Good & 20.26 & Good \\
\hline Significance Probability & $\geq 0.05$ & 0.26 & Good & 0.36 & Good \\
\hline RMSEA & $\leq 0.08$ & 0.03 & Good & 0.02 & Good \\
\hline CMIN/DF & $\leq 2.00$ & 1.16 & Good & 1.08 & Good \\
\hline GFI & $\geq 0.90$ & 0.97 & Good & 0.97 & Good \\
\hline AGFi & $\geq 0.90$ & 0.94 & Good & 0.95 & Good \\
\hline TLI & $\geq 0.90$ & 0.99 & Good & 0.99 & Good \\
\hline CFI & $\geq 0.95$ & 0.97 & Good & 0.99 & Good \\
\hline
\end{tabular}

notes (1) result, (2) model evaluation. * Expected to be low.

TABLE 2 Full Model Structural Goodness of Fit Induces Before and After Modification

\begin{tabular}{llrrrrr}
\hline Goodness of Fit Indices & Cut-off & \multicolumn{2}{c}{ Before modification } & & \multicolumn{2}{c}{ After modification } \\
& Value & & $(1)$ & $(2)$ & $(1)$ & $(2)$ \\
\hline Chi-Square & $*$ & 172.92 & Good & & 58.88 & Good \\
Significance Probability & $\geq 0.05$ & 0.00 & Bad & & 0.37 & Good \\
RMSEA & $\leq 0.08$ & 0.05 & Bad & 0.02 & Good \\
CMIN/DF & $\leq 2.00$ & 1.57 & Good & & 0.15 & Good \\
GFI & $\geq 0.90$ & 0.91 & Good & & 0.96 & Good \\
AGFi & $\geq 0.90$ & 0.88 & Marginal & & 0.93 & Good \\
TLI & $\geq 0.90$ & 0.94 & Good & & 0.99 & Good \\
CFI & $\geq 0.95$ & 0.95 & Good & 0.99 & Good \\
\hline
\end{tabular}

Notes (1) result, (2) model evaluation. * Expected to be low.

Having passed the CFA for both constructs of exogenous and endogenous, we test the full model to make sure that the model was fit. The result of the model fit test was reported in table 2 . Unfortunately, even though the full model had passed the CFA, it was found not fit since the score of three criteria was not good as expected. They are the chi-square (172.92), the significance probability (0.00), and the AGFI (o.88). Therefore checking the validity of all instruments must be done. Items with a loading factor of less than 0.5 were not valid and must be cut (Hair et al. 2010). All loading factor revealed four invalid items. They are buying unnecessary products (0.178); using products that are favored by friends (0.013); keeping track on the money (o.009); and considering borrowing as the easiest way to get money (0.013). After cutting those four items, the model fit test was done again and indicated that the model was fit.

After all indicators that had passed the validity test, we conduct 
TABLE 3 Validity and Reliability Coefficient

\begin{tabular}{|c|c|c|c|}
\hline Variable & Items & (1) & (2) \\
\hline \multirow[t]{3}{*}{ СвB } & I often have spontaneous desire to shop & 0.805 & 0.904 \\
\hline & I find it isn't hard to restrain my self not to shop & 0.803 & \\
\hline & I believe that shopping is a way to face the stress & 0.784 & \\
\hline \multirow{3}{*}{$\begin{array}{l}\text { Peer } \\
\text { acceptance }\end{array}$} & I use trendy products to get acceptance & 0.865 & 0.939 \\
\hline & I use high-quality products to get acceptance & 0.803 & \\
\hline & I often follow friends to buy certain products & 0.907 & \\
\hline \multirow{3}{*}{$\begin{array}{l}\text { Money } \\
\text { retention }\end{array}$} & I don't easily spend money & 0.812 & 0.896 \\
\hline & I am capable of managing money & 0.810 & \\
\hline & When I have more money, I save it & 0.732 & \\
\hline \multirow{3}{*}{$\begin{array}{l}\text { Borrowing } \\
\text { habit }\end{array}$} & I try as much as possible not to borrow money & 0.801 & 0.903 \\
\hline & I will not think carefully before borrowing money & 0.840 & \\
\hline & $\begin{array}{l}\text { I am not used to borrowing money, even though } \\
\text { I am in need }\end{array}$ & 0.881 & \\
\hline
\end{tabular}

Notes (1) estimate, (2) construct reliability.

the reliability test by calculating the construct reliability score. The result of the calculation reported in table 3 showed that the lowest score was only 0,896 , shown by money retention. They passed the reliability test because they had above 0.7 cutoff value, as recommended (Hair et al. 2010).

Before performing the model testing, the data was required to be normally distributed. Here to check the normality of the data by using critical ratio. The standard score used for the evaluation was \pm 2.58 . The maximum score of critical ratio was 1.954 , while the minimum score of critical ratio was -1.603 and the overall measure was 2.390. It was less than the standard score +2.58 so the data in this study was normally distributed in multivariate level.

Table 4 reported and proved that свв would lead to a high borrowing habit since the effect was significantly positive. свв itself was affected by peer acceptance and money retention. However, pocket money was not proved as a determinant of свB. A borrowing habit that affected by свв was also affected directly by a factor that influences свв. It was money retention. Meanwhile, pocket money and peer acceptance did not affect borrowing habit. Therefore, only money retention had the direct and the indirect effect on borrowing habit. The result of this mediating effect was concluded by using the three steps test. The first step was to see the money retention influence on borrowing habit. The influence was significant and the standardized estimation was -0.543 . The second step was to see the effect of money retention on свв as the intervening variable, which 
TABLE 4 Regression Weights

\begin{tabular}{lrrrc}
\hline Item & $(1)$ & $(2)$ & $(3)$ & $(4)$ \\
\hline СВВ $\leftarrow$ Money Retention & -0.371 & 0.085 & -4.371 & $0.000^{* * *}$ \\
СВВ $\leftarrow$ Peer Acceptance & 0.289 & 0.072 & 4.045 & $0.000^{* * *}$ \\
Свв $\leftarrow$ Pocket Money & 0.041 & 0.051 & 0.805 & 0.421 \\
Borrowing Habit $\leftarrow$ Pocket Money & -0.017 & 0.053 & -0.319 & 0.750 \\
Borrowing Habit $\leftarrow$ Peer Acceptance & -0.083 & 0.077 & -1.077 & 0.282 \\
Borrowing Habit $\leftarrow$ Money Retention & -0.549 & 0.101 & -5.418 & $0.000^{* * *}$ \\
Borrowing Habit $\leftarrow$ свв & 0.172 & 0.097 & 1.775 & $0.076^{*}$ \\
\hline
\end{tabular}

Notes (1) estimation, (2) standard error, (3) critical ratio, (4) $p$-value, *** significant at $1 \%$, * significant at $10 \%$.

resulted in a significant effect. The last step was to see the effect of money retention on borrowing habit by adding свв as an additional predictor too. The effect was found to be significant, but the standardized estimation was -0.413 . The estimation was lower than the estimation in the first step (-0.543 to -0.413). Therefore, partial mediation was supported. Money retention effect on borrowing habit was proved to be mediated by свв.

\section{Discussion}

Previous studies had shown differences in results with regard to the effect of pocket money and income towards свв. Faber, O'Guinn, and Krych (1987) stated that the свв problem might be confined to the middle or lower income individuals with eagerness to purchase things and little willpower to resist the urges. The different result came from Ergin (2010) who discovered that the level of income was a significant predictor of свв. This study, however, appeared to clarify that compulsive buyers tend to come from all income groups as stated by O'Guinn and Faber (1989) and Scherhorn, Reisch, and Raab (1990). The additional information showed that the students' biggest spending was for food, telecommunication, and also for printing and copying papers and books. Besides, only a few of them had mentioned clothes, shoes, and makeup as their biggest spending. After spending much of their money on basic needs as students, many of them only had a little money left to save. However, most of the students still saved it. This habit proved that how much pocket money they received every month did not matter since they still preferred spending money on their basic needs and saving the rest of their money to spending it on buying things they did not need.

Although pocket money did not affect свв, there were many antecedents of свв revealed by previous studies. Personality was a 
widely examined attribute that proved as a factor that influenced свв. Shahjehan et al. (2012), for example, had examined the impact and effect of Big Five Personality Traits on свв. Their investigation proved that свв was positively influenced by the personality traits, even not by all of them. The same result also came from the research conducted by Milkolajczak-Degrauwe et al. (2012).

Chaplin and John (2010) commented on the relationship between peer acceptance and buying behavior: 'when adolescents communicate their consumption with their peers and see their peers' avid desires, they likely to model the same behavior to crave for similar things that their peers want or have.' Furaiji, Latuzynska, and Mawrzyniak (2012) also stated that reference groups have a significant influence on consumers' purchasing behaviors. The result of the current study was in line with the comment of Chaplin and John (2010) and Furaiji, Latuzynska, and Mawrzyniak (2012).

This study also proved that by having high money retention, the students are capable of restraining themselves to be compulsive buyers. They were able to manage their pocket money, even saving the remaining of their money as reported by the additional information that most of the students had to save. They did not spend money easily on buying things they did not need since they were capable of managing their pocket money. Therefore, the students could control themselves to be compulsive buyers. Wong (2010) stated that high money retention directed people to avoid unplanned purchases. The СвВ is one form of the unplanned purchases.

Another finding of this study was that higher pocket money did not lead the students to have a high tendency of borrowing habit. Interestingly, even though the result is not significant, the proposition that pocket money affects the borrowing habit was found to be negative. It may be people with a large amount of pocket money had enough money to cover their needs and wants. On the other side, people who had limited or a small amount of pocket money would need extra money to meet their needs and desires. Therefore, they would borrow money to get extra money. The more they asked their peers to lend them some money because of their needs of extra money, the higher their borrowing habit would be. Peer acceptance was not found to be a predictor of borrowing habit in this study. Although it was not significant, the peer acceptance effect towards borrowing habit was negative. The students might think that borrowing money would make them look like 'poor' students in front of their friends. Thus, borrowing money might be seen as a way of getting the rejection from their friends. Then, it could be said that 
the higher their peer acceptance was, the more careful they would decide whether to borrow money.

Money retention would help the students controlling and reducing their tendency to borrow money from their friends or relatives. The result confirmed that people who had most loans were the ones that knew the least about how to manage their money effectively and efficiently. The ability to manage their pocket money lead them to make saving even with limited pocket money. They also seldom experienced a lack of money since they were capable of managing it. This finding was in line with the study of Dittmar (2005) and Wilczaki (2006).

Money retention was very important for people since, in this study, it was found to have a negative effect on both borrowing habit and свв. Students' ability to manage their pocket money brought them to a safe financial situation where they seldom experienced a lack of money. This capability also helped them to prevent themselves from being recurrent borrowers. This study also proved that the effect of money retention towards borrowing habit was mediated by свв. It was the necessity to purchase something that now became a trigger for people to borrow money, especially when they wanted to buy things but they did not have any money. It was about consuming things at the moment that led people to borrow money. This logical thinking was supported by Andreou (2011) who provided an example of the need to buy things at the moment and the need to borrow money. She noted that for the people who were expecting higher income in the future, when they wanted to consume more than their present income allowed them to, it still could be done by borrowing money.

\section{Limitations and Future Research}

This study does have certain limitations. Most of the students involved in this study were female and came from out of town. The likely balanced percentage of gender and origin is also important to be analyzed since these differences may affect the result. Some previous studies indicated that peer acceptance and money retention might differ between male and female and that ethnicity might have the effect on свв and borrowing habit. Therefore, by obtaining a balance proportion of students in case of gender and origin, it is expected to obtain a more accurate result. It must be noted that undergraduate students have certain behaviors and attitudes, which may vary from other people as well.

Thus, the result of this study cannot be generalized to the public or 
another group of people, except by adopting the model to a different group of people.

\section{References}

Andreou, S. N. 2011. 'The Borrowing Behavior of Households: Evidence from the Cyprus Family Expenditure Surveys.' Cyprus Economic Policy Review 5(2): 57-83.

Bearden, W. O., R. G. Netemeyer, and J. E. Teel. 1989. 'Measurement of Consumer Susceptibility to Interpersonal Influence.' Journal of Consumer Research 15 (4): 473-81.

Bentler, P. M., and C. Chou. 1987. 'Practical Issues in Structural Modeling.' Sociological Methods and Research 16:78-117

Bhardwaj, S., and K. Bhattacharjee. 2010. 'Modeling Money Attitudes to Predict Loan Default.' Journal of Bank Management 9 (1): 12-20.

Bindah, E. V., and M. N. Othman. 2012. 'The Tantalizing Factors Associated with Compulsive Buying among Young Adult Consumers.' International Business and Management 4 (2): 16-27

Black, D. W. 2007. 'A Review of Compulsive Buying Disorder.' World Psychiatry February 6 (1): 14-8.

Bonke, J. 2013. 'Do Danish Children and Young People Receive Pocket Money?' Study Paper 57:1-12.

Bristol, T., and T. Mangleburg. 2005. 'Not Telling The Whole Story: Teen Deception in Purchasing.' Journal of the Academy of Marketing Science 33 (1): 79-95.

Callender, C., and J. Jackson. 2005. 'Does the Fear of Debt Deter Students from Higher Education?' Journal of Social Policy 34 (4): 509-40.

Chaplin, L. N., and D. R. John.2010. 'Interpersonal Influences on Adolescent Materialism: A New Look at the Role of Parents and Peers.' Journal of Consumer Psychology 20 (2): 176-84.

Luna De La Rosa, M. 2012. 'Borrowing and Working of Low-Income Students: The Impact of a Summer Transition Program.' Journal of Students Financial Aid 42 (1): 5-15.

DeSarbo, W. S., and E. A. Edwards. 1996. 'Typologies of Compulsive Buying Behavior: A Constrained Clusterwise Regression Approach.' Journal of Consumer Psychology 5 (3): 231-62.

Dittmar, H. 2005. 'A New Look at "Compulsive Buying:" Self-Discrepancies and Materialistic Values as Predictors of Compulsive Buying Tendency.' Journal of Social and Clinical Psychology 24 (5): 832-59.

Edwards, E. A. 1993. 'Development of a New Scale for Measuring Compulsive Buying Behavior.' Financial Counseling and Planning 4:67-84.

Engelberg, E., and L. Sjoberg. 2006. 'Money Attitudes and Emotional Intelligence.' Journal of Applied Social Psychology 36 (8): 2027-47.

Ergin, E. A. 2010. 'Compulsive Buying Behavior Tendencies: The Case of Turkish Consumers.' African Journal of Business Management 4 (3): 333-8. 
Faber, R. J., T. C. O'Guinn, and R. Krych. 1987. 'Compulsive Consumption.' In Advances in Consumer Research, edited by M. Wallendorf and P. Anderson, 132-135. Provo, U T: Association for Consumer Research.

Flynn, L., and D. Pearcy. 2001. 'Four Subtle Sins in Scale Development: Some Suggestions for Strengthening the Current Paradigm.' International Journal of Market Research 43 (4): 409-33

Furnham, A. 1984. 'Many Sides of the Coin: The Psychology of Money Usage.' Personality and Individual Differences 5 (5): 501-9.

- 1999. 'The Saving and Spending Habits of Young People.' Journal of Economic Psychology 20 (6): 677-97.

Furaiji, F., M. Latuzynska, and A. Mawrzyniak. 2012. 'Empirical Studies of the Factors Influencing Consumer Behaviour in the Electric Appliances Market.' Contemporary Economics 6 (3): 76-86.

Gifford-Smith, M. E., and C. A. Brownell. 2002. 'Childhood Peer Relationships: Social Acceptance, Friendships, and Peer Networks.' Journal of School Psychology 41:235-84.

Guo, Z., and Y. Cai. 2011. 'Exploring the Antecedents of Compulsive Buying Tendency among Adolescents in China and Thailand: A Consumer Socialization Perspective.' African Journal of Business Management 5 (24): 10198-209.

Hair, J. F., W. C. Black, B. J. Babin, and R. F. Anderson. 2010. Multivariate Data Analysis: A Global Perspective. 7th ed. Upper-Saddle River, NJ: Pearson.

Jalees, T. 2007. 'Identifying Determinants of Compulsive Buying Behavior.' Market Forces 3 (2): 30-51.

Kelman, H. 1961. 'Process of Opinion Change.' Public Opinions Quarterly 25 (Spring): 57-78.

Khaniwale, M. 2015. 'Consumer Buying Behavior.' International Journal of Innovation and Scientific Research 14 (2): 278-86

Li, D., Y. Jiang, S. An, Z. Shen, and W. Jin, 2009. 'The Influence of Money Attitudes on Young Chinese Consumers' Compulsive Buying.' Young Consumers Insight and Ideas for Responsible Marketers 10 (2): 98109.

Lin, C. H., and H. M. Lin. 2005. 'An Exploration of Taiwanese Adolescents' Impulsive Buying Tendency.' Adolescence 40 (Spring): 215-23.

Linenmeier, D. M., H. S. Rosen, and C. E. Rouse. 2006. 'Financial Aid Packages and College Enrollment Decisions: An Econometric Case Study.' Review of Economics and Statistics 88 (1): 126-45.

McElroy, S., P. Keck, H. Pope, J. Smith, and S. Strakowski. 1994. 'Compulsive Buying: A Report of 20 Cases.' Journal of Clinical Psychiatry $55(6): 242-8$.

Milkolajczak-Degrauwe, K., G. Rossi, B. Wauters, and M. Brengman. 2012. 'Can We Identify Compulsive Buyers Based on Their Personality?' Journal of Customer Behavior 11 (3): 221-40. 
Moschis, G. P., A. Mathur, C. K. Fatt, and C. Pizzutti. 2013. 'Effects of Family Structure on Materialism and Compulsive Consumption: A Life Course Study in Brazil.' Journal of Research for Consumers 23 (4): 66-96.

O'Guinn, T. C., and R. Faber. 1989. 'Compulsive Buying: A Phenomenological Exploration.' Journal of Consumer Research 16 (2): 47-157.

Ponchio, M. C., and F. Aranha. 2008. 'Materialism as a Predictor Variable of Low Income Consumer Behavior When Entering into Installment Plan Agreements.' Journal of Consumer Behaviour 7 (1): 21-34.

Rindfleisch, A., J. E. Burroughs, and F. Denton. 1997. 'Family Structure, Materialism, and Compulsive Consumption.' Journal of Consumer Research 23 (4): 312-25.

Scherhorn, G., L. A. Reisch, and G. Raab. 1990. 'Addictive Buying in West Germany: An Empirical Study.' Journal of Consumer Policy 13 (4): 355-87.

Shahjehan, A., J. A. Qureshi, F. Zeb, and K. Saifullah. 2012. 'The Effect of Personality on Impulsive and Compulsive Buying Behaviors.' African Journal of Business Management 6 (6): 2187-94.

Slaughter, V., M. Dennis, and M. Prichard. 2002. 'Theory of Mind and Peer Acceptance in Preschool Children.' British Journal of Developmental Psychology 20:545-64.

Taneja, R. M. 2012. 'Money Attitude - An Abridgement.' Journal of Arts, Science and Commerce 3 (3): 94-8.

Valence, G., A. d'Astous, and L. Fortier. 1988. 'Compulsive Buying: Concept and Measurement.' Journal of Consumer Policy 11 (4): 419-33.

Vicdan, H., and J. Sun. 2008. 'Towards a Framework for Understanding Compulsive Buyers Online: Exploring the Effects of Online Sales Promotions.' Proceedings of the 2008 Southwest Decision Science Institute (DSI) Meeting. 598-607. Houston, TX: Southwest Decision Science Institute.

Wilczaki, A. R. 2006. 'Understanding Compulsive Buying: The Dimensions and Management of Addictive Shopping.' Master Dissertation, Eastern Michigan University, Ypsilanti, MI.

Wong, J. 2010. 'An Analysis of Money Attitudes: Their Relationships and Effects on Personal Needs, Social Identity and Emotions.' Journal of Leadership, Accountability and Ethics 8 (1): 57-64.

Workman, L., and D. Paper. 2010. 'Compulsive Buying: A Theoretical Framework.' The Journal of Business Inquiry 9 (1): 89-126.

Yamauchi, K. T., and D. I. Templer. 1982. 'The Development of a Money Attitude Scale.' Journal of Personality Assessment 46 (5): 522-9. 